Dr TATJANA MILOŠEVIĆ, istraživač-saradnik

Institut za strategijska istraživanja

Beograd, Republika Srbija

tatjana74.milosevic@gmail.com

originalan naučni rad

UDK: 327(497.1:73)"1970/1974"

primljeno: 22. januar 2018.

prihvaćeno: 16. maj 2018.

https://doi.org/10.29362/ist20veka.2018.2.mil.187-202

\title{
JUGOSLAVIJA I SJEDINJENE AMERIČKE DRŽAVE U VREME DETANTA: SUSRETI JOSIPA BROZA TITA I HENRIJA KISINDŽERA 1970. I 1974.
}

APSTRAKT: U članku su analizirane osnovne determinante i sadržajne odrednice jugoslovensko-američkih odnosa tokom perioda detanta sa posebnim osvrtom na posetu državnog sekretara i savetnika za nacionalnu bezbednost Henrija Kisindžera Jugoslaviji. Izložen je čitav splet unutrašnjih i spoljnih faktora koji su predstavljali prepreku za unapređenje bilateralne saradnje. Međutim, obostrani interes za očuvanje stabilnih odnosa i nezavisne Jugoslavije doveo je do prevazilaženja razlika u gledištima i favorizovanja svega onoga što je Jugoslaviju i SAD povezivalo i upućivalo na saradnju. Poseban doprinos unapređenju bilateralne saradnje omogućen je Kisindžerovom posetom Jugoslaviji. Članak je nastao na osnovu istraživanja građe Arhiva Jugoslavije, Diplomatskog arhiva Ministarstva spoljnih poslova Republike Srbije i korišćenja relevantne literature.

KLJUČNE REČI: Jugoslavija, Sjedinjene Američke Države, Josip Broz Tito, Henri Kisindžer, Ričard Nikson, Džerald Ford, nesvrstane zemlje, bliskoistočna i kiparska kriza

\section{Razdoblje Niksonove administracije i američka spoljna politika}

Jedan od dominantnih tokova od 1969. godine, posle izbora novog američkog predsednika (republikanskog kandidata Ričarda Niksona) i administracije, bila je realnija američka politika koja je imala cilj da dovede do popuštanja zategnutosti između SAD i preostale dve velike sile (SSSR i Kina). Izborom Niksona za američkog predsednika 1968. godine Henri Kisindžer ${ }^{1}$ postaje zvanični predsednikov savetnik za pitanja nacionalne bezbednosti. Američka poli-

\footnotetext{
${ }^{1}$ Henri Kisindžer je rođen u Nemačkoj 1923. godine. S obzirom na jevrejsko poreklo, zbog pogroma Jevreja iz Hitlerove Nemačke bio je primoran da beži sa roditeljima u Sjedinjene Američke Države 1938. godine. Od 1943. zvanično postaje državljanin SAD. Tamo završava Harvard univerzitet na kome i doktorira 1954. godine. Izborom Niksona za američkog predsednika 1968. Kisindžer postaje zvanični predsednikov savetnik za pitanja nacionalne bezbednosti.
} 
tika tokom 1969. nije težila pogoršanju odnosa ni sa jednom zemljom sveta, već su Sjedinjene Države naprotiv vršile pokušaje repariranja odnosa ili opreznog stvaranja uslova za njihovo poboljšanje. SAD su se generalno zalagale za tzv. lower profile (prisustvo koje manje štrči), to jest za politiku nižeg profila. Međutim, taj niži profil se odnosio na opreznije i manje vojno prisustvo SAD u raznim delovima sveta. Istovremeno je značio i veće ekonomsko i naučno prisustvo SAD gde god je to bilo moguće.

Izborom republikanskog kandidata Ričarda Niksona za američkog predsednika usledili su krupni zaokreti u jugoslovensko-američkim odnosima. Profil i obim odnosa između Jugoslavije i SAD postao je veći nego ranije. SAD su bile sve prisutnije u Jugoslaviji i to na ekonomskom, kulturnom i političkom nivou. $^{2}$ Dakle, SAD su adaptirale svoju politiku u pravcu izbegavanja konfrontacija i u okretanju prema diplomatskim rešenjima što je trebalo da postane $\mathrm{i}$ dugoročna orijentacija. Sjedinjene Države su i dalje pokazivale neopredeljenost između preostale dve velike sile (SSSR i Kine) i zalagale su se protiv udruživanja dve države na račun treće.

Sjedinjene Države su u ovom periodu javno formulisale opredeljenje za politiku trojnog balansa. Takođe su formulisale i politiku u svom bloku tzv. community of powers, koja je podrazumevala veća prava i samostalnost za partnere, te politiku ,ko nije protiv nas, sa nama je“ (odnosno kako je Nikson rekao u inauguralnoj adresi: Ako već ne možemo da od svakog napravimo našeg prijatelja, bar ne pravimo neprijatelje). U skladu sa takvom politikom SAD su nastavile liniju mnogostrukih razgovora, umanjivanja konfrontacija sa SSSR-om na bazi nuklearnih pariteta (SALT, bilaterala). Potom su usledile određene mere otvaranja, popuštanja prema Kini, smanjenje antikineske propagande, dezangažovanje u Vijetnamu, korigovanje stava na Bliskom istoku koje je dovelo do protesta i zabrinutosti Izraela i jevrejskih organizacija u SAD. Vođenjem takve politike Sjedinjene Države su stvarale prostor za dejstvo srednjih, manjih sila, nezavisnih i nesvrstanih zemalja s obzirom na sve tolerantniji američki stav prema politici nesvrstavanja. ${ }^{3}$

Američki predsednik Nikson je u jednom oficirskom klubu u Guamu proklamovao novu političku liniju nazvanu Guamska doktrina koja je vremenom prerasla u tzv. Niksonovu doktrinu. Prema toj doktrini SAD su se pridržavale svojih ugovornih obaveza i bile su spremne da pod pretnjom nuklearne sile štite slobodu zemlje koja je bila u savezu sa njima ili čiji je opstanak bio vitalan za sigurnost SAD, dok bi u slučajevima drugih vrsta agresije Amerikanci bili spremni na pružanje vojne i ekonomske pomoći kada bi to bilo traženo od njih na odgovarajući način. Od direktno ugrožene zemlje, međutim, Amerikanci su očekivali preuzimanje osnovne odgovornosti u prikupljanju ljudstva za svoju odbranu. ${ }^{4}$ Moglo bi se reći da je Niksonova doktrina u izvesnoj meri popravila sliku SAD u svetu i da je smirila „duhove u kući“, čemu je najviše doprinelo

\footnotetext{
${ }^{2}$ Diplomatski arhiv Ministarstva spoljnih poslova Republike Srbije (DA MSP), Politička arhiva (PA), 1970, SAD, f-165, 48273, Američka politika.

${ }^{3}$ DA MSP, PA, 1969, SAD, f-164, 41591, Politika SAD u kontekstu trougla sila tokom 1969.

${ }^{4}$ Henri Kisindžer, Memoari I (Zagreb: Vjesnikova Press agencija, 1981), 229-243.
} 
smanjenje američkih vojnih snaga u Vijetnamu. Prema Niksonovim ubeđenjima i međunarodna ekonomska politika je predstavljala važnu dimenziju mira. ${ }^{5}$

Predsednik Nikson je poverio obavljanje najvažnijih zadataka vezanih za američku spoljnu politiku svom savetniku za nacionalnu bezbednost Henriju Kisindžeru. Jedan od glavnih arhitekata politike međuzavisnosti u SAD upravo je bio Kisindžer koji je u svojim političkim esejima pokušavao da teoretski odredi raniju politiku sporazumevanja između velikih sila. U sklopu tih aktivnosti Kisindžer početkom 70-ih godina boravi u dve tajne misije, najpre u NR Kini a potom i u SSSR-u gde vredno radi na pripremama za posetu američkog predsednika Niksona tim zemljama. Vest o Kisindžerovoj poseti Pekingu (od 9. do 11. jula 1971) odjeknula je u tom periodu svetom poput bombe. ${ }^{6}$ Radi uspostavljanja balansa u triangularnom odnosu velikih sila Kisindžer je bio spreman da poseti i SSSR i da tom prilikom poradi na pripremama oko zaključenja Sporazuma o ograničenju naoružanja poznatog kao SALT I i Sporazuma o ograničenju broja strateških raketa ABM.

U skladu sa američkim spoljnopolitičkim ciljevima Niksonova administracija je na početku mandata pokazivala malo interesovanja za situaciju na Bliskom istoku. Umesto preduzimanja neophodnih koraka u pravcu smirivanja tenzija na tom području, američka administracija je radila na tome da postane glavni snabdevač Izraela oružjem. Rešavanje bliskoistočne krize je prepustila državnom sekretaru Vilijamu Rodžersu, što je ukazivalo na činjenicu da su američki čelni ljudi imali preča posla. Zato je i predsednikov savetnik za nacionalnu bezbednost Kisindžer u početku bio suzdržan od mešanja u izraelsko-arapski sukob s obzirom na svoje jevrejsko poreklo. Međutim, Jomkipurski rat 1973. godine brzo ga je pokrenuo na akciju. Tako je od pasivnog posmatrača Kisindžer postao glavni akter pregovora o prekidu rata između sukobljenih strana. ${ }^{7} \mathrm{U}$ cilju rešavanja bliskoistočne krize tokom proleća 1974. godine, Kisindžer je otpočeo sa procesom ,ک̌atl diplomatije“, boraveći na relaciji Kairo-Jerusalim radi postizanja sporazuma o povlačenju vojnih snaga dve zemlje. Kisindžerov veliki doprinos miru - pored pokušaja da reši bliskoistočnu krizu - ogledao se i u vođenju pregovora koji su imali za cilj okončanje rata u Vijetnamu, zahvaljujući kojima je postao dobitnik Nobelove nagrade za mir decembra 1973. godine. ${ }^{8}$

Prema nesvrstanim zemljama Kisindžer je primenjivao selektivnu politiku i različite kriterijume u odnosu na pojedine zemlje, zavisno od potreba američke politike i konkretnih uslova. Kao američki državni sekretar i savetnik za nacionalnu bezbednost u okviru načela američke spoljne politike nastojao je da neke značajnije nesvrstane zemlje kroz bilateralnu saradnju veže za SAD,

\footnotetext{
${ }^{5}$ DA MSP, PA, 1970, SAD, f-165, 48273, Američka politika.

${ }^{6}$ Sanja Radović, ,Jugoslovenski pogled na kinesku politiku otvaranja u periodu 1970-1972. godine“, Tokovi istorije, br. 2, (2013), 234-235. Više o tome: Marvin Kalb and Bernard Kalb, Kissinger (New York: Dell Publishing, 1974), 96-272.

7 Robert D. Šulcinger, Američka diplomatija od 1900. godine (Beograd: Udruženje za studije SAD u Srbiji, 2011), 292-293.

${ }^{8}$ Isto, 296-297. Više o tome: Matti Golan, The secret conversations of Henry Kissinger. Step by step diplomacy in the Middle East (New York: Quadrangle The New York Times Book, 1976), 179-253.
} 
kanališe ih na usku regionalnu politiku i otupi oštricu njihove antiimperijalističke borbe. ${ }^{9}$ Međutim, razvoj međunarodnih događaja a posebno Četvrta konferencija nesvrstanih u Alžiru 1973. godine uticali su na promenu političkog stava Sjedinjenih Država prema tim zemljama u smislu da se na njih počelo gledati kao na snagu sa kojom se moralo ozbiljno računati. U skladu sa promenama $u$ međunarodnim odnosima američki državni sekretar Kisindžer je 1973. godine u Ujedinjenim nacijama nazvao politiku nesvrstanosti ,svrstavanjem u novi blok“. Zbog politike prema zemljama Trećeg sveta Kisindžer je smatran jednim od kontradiktornih političara ere Hladnog rata. Iz jugoslovenskog ugla novi momenti u spoljnoj politici SAD širili su prostor politici miroljubive koegzistencije. Uspeh ili neuspeh nove američke orijentacije zavisio je od niza elemenata, a pre svega od njihove realizacije u praksi. ${ }^{10}$

\section{Prva Kisindžerova poseta Jugoslaviji 1970. godine}

U novonastaloj spoljnopolitičkoj situaciji položaj malih i srednjih zemalja, posebno nesvrstanih (među kojima se nalazila i Jugoslavija) i nerazvijenih postajao je sve složeniji i teži, ali su se istovremeno otvarale i nove mogućnosti za akcije tih zemalja. Pri tom su bili korišćeni svi faktori koji su mogli da deluju limitirajuće na politiku i strategiju supersila (nuklearni faktor, dezintegracioni procesi unutar paktova, narastanje uloge međunarodne demokratske javnosti, OUN). ${ }^{11}$

Na Balkanskom poluostrvu granica koja je delila interese Istoka i Zapada nije bila tako čvrsto fiksirana $\mathrm{i}$ zato je Jugoslavija posebno predstavljala područje živog interesa velikih sila i njihovih mogućih nagodbi. U to vreme jugoslovensko-američki odnosi su bili opterećeni uzajamnim neslaganjima oko puteva razrešenja dva krupna međunarodna problema - bliskoistočne i vijetnamske krize. Jugoslovenski zvaničnici su i dalje u svojim nastupima SAD smatrali glavnim krivcem za eskalaciju sukoba na Bliskom istoku i u Vijetnamu. Takav jugoslovenski stav je uticao na kolebanja američkih zvaničnika oko pitanja svrsishodnosti pružanja političke i ekonomske podrške Jugoslaviji. U ovo vreme tekle su i pripreme za Pripremni sastanak za samit nesvrstanih koji je održan septembra meseca 1970. Na toj Konferenciji šefova ili vlada vanblokovskih država u Lusaki, zemlje učesnice su podržale Titov predlog o potrebi organizovanog zajedničkog nastupa u međunarodnim odnosima. Tom prilikom su

\footnotetext{
${ }^{9}$ Dragan Bogetić, Jugoslovensko-američki odnosi u vreme bipolarnog detanta 1972-1975 (Beograd: Institut za savremenu istoriju, 2015), 192-207.

${ }^{10}$ DA MSP, PA, 1969, SAD, f-158, 428078, Novi momenti u spoljnoj politici SAD; Arhiv Jugoslavije (AJ), Kabinet Predsednika Republike (KPR), I-3-a/107-212. SAD i politika nesvrstavanja. Nastup Predsednika Forda na XXIX redovnom zasedanju GS UN; AJ, KPR, I-5-c/21. Sednica Saveta za nacionalnu bezbednost. Primena vojnih mera; AJ, KPR, I-5-b/104-20. Kisindžerov intervju časopisu „Busines week“, januar 1975. Izjava o mogućoj upotrebi vojne sile; AJ, KPR, I5-c/25. Kisindžerov govor u Misuriju, 15. maj 1975; Fordov govor na Universitetu Viskonsin instituta za svetske poslove u Milvokiju, 14. jul 1975; H. Kissinger, A Just Consensus, A Stable Order, A Durable Peace, An Address made before the 28th Session of United Nations General Assembly, September 24, 1973, „Department of State Bulletin“, October 15, 1973, p. 470.

${ }^{11}$ DA MSP, PA, 1970, SAD, f-8, 3, Osnovne promene i kretanja u međunarodnim odnosima.
} 
stvoreni i posebni uslovi za formiranje stalnih tela za koordinaciju aktivnosti tih zemalja. U toj organizaciji vanblokovskih država Jugoslavija je uspela da izbori lidersku poziciju što joj je omogućilo da igra značajnu ulogu u međunarodnim odnosima. Konferencija nesvrstanih zemalja u Lusaki predstavljala je prekretnicu u jugoslovensko-američkim odnosima i doprinela je podizanju interesa američkog predsednika da poseti Beograd. ${ }^{12}$

Pre zvanične posete američkog predsednika Jugoslaviji došlo je do susreta predsednika Jugoslavije sa američkim državnim sekretarom Rodžersom. Tom prilikom je samo bio potvrđen zvaničan stav američke politike prema Jugoslaviji, koji se temeljio na podršci opstanku nezavisne Jugoslavije. ${ }^{13}$ Niksonov put u Jugoslaviju je bio diktiran spoljnim (nezadovoljavajući razvoj situacije na Bliskom istoku i Sredozemlju) i unutrašnjim razlozima (pred izbore u SAD bilo je potrebno pokazati odlučnost i autoritet SAD i Šeste flote). Na spoljnom planu poseta Jugoslaviji je trebalo da pokaže da su Amerikanci konačno bili spremni na razgovore i kompromise. Istovremeno poseta je trebalo da bude i demonstracija šireg američkog prilaza u odnosima sa Sovjetima budući da je Jugoslavija predstavljala važan faktor stabilnosti na Balkanu, na glavnom izlazu za Sredozemlje. Amerikanci su smatrali da će Jugoslavija biti u mogućnosti da računa na njihovu podršku sve dotle dok bude vodila politiku vojne i ideološke nezavisnosti prema Sovjetskom Savezu i Kini. ${ }^{14}$

Američki savetnik za nacionalnu bezbednost Kisindžer smatrao je Jugoslaviju korisnim faktorom za SAD kako zbog Balkana tako i zbog Istočne Evrope ali i simbolom nezavisnosti u odnosu na zemlje Istočnog bloka. Jugoslovenska autonomija u odnosu na Sovjete omogućavala je veći uticaj u svetu u razvoju nego što je to bilo realno moguće u bilo kojem satelitskom režimu Istočne Evrope. Van evropskog kontinenta, međutim, jugoslovenska politika je sledila uverenja koja nisu bila naklonjena zapadnim interesima. To se najbolje ogledalo kroz naklonost prema revolucijama u zemljama u razvoju, u čemu se ta politika nije razlikovala od moskovske. S druge strane, prema Kisindžerovim shvatanjima, jugoslovenska samostalnost je uticala na poboljšanje američke globalne pozicije s obzirom na to da se sigurnost Evrope povećavala Titovim odbijanjem da se priključi Varšavskom paktu. ${ }^{15}$

Do prvog susreta američkog državnog sekretara Kisindžera sa predstavnicima jugoslovenske vlasti došlo je tokom Niksonove posete Jugoslaviji 1970. godine (od 30. septembra do 2. oktobra) u svojstvu njegovog savetnika za nacionalnu bezbednost. Niksonova poseta Jugoslaviji je usledila posle Konferencije nesvrstanih u Lusaki koja je održana od 8. do 10. septembra, a pred jubilarno zasedanje Generalne skupštine OUN, odnosno u vreme vidljive afirmacije pozi-

12 Dragan Bogetić, Jugoslovensko-američki odnosi 1961-1971 (Beograd: Institut za savremenu istoriju, 2012), 170-174.

13 DA MSP, PA, 1970, SFRJ, f-9, 18, Susret predsednika Tita sa državnim sekretarom Rodžersom, 26. februara 1970. godine.

${ }^{14}$ DA MSP, PA, 1970, SFRJ, f-170, 447718, Izveštaj ambasadora B. Crnobrnje iz Vašingtona 22. decembra 1970.

${ }^{15}$ H. Kisindžer, Memoari II, 142-146. Opširnije o tome u: Milan Terzić, Tito i Nobelova nagrada za mir (Podgorica: Pobjeda, 2006), 26-30. 
cije i uticaja Jugoslavije u međunarodnim odnosima i bila je značajan uspeh jugoslovenske spoljne politike. ${ }^{16}$ Ova poseta je doprinela razbijanju predrasuda u odnosima između dve zemlje i ujedno je predstavljala novi kvalitet u odnosima zahvaljujući preovladavanju realizma u američkoj politici. ${ }^{17}$

Američki državni sekretar Kisindžer je kasnije u svojim Memoarima izneo zabelešku o tom susretu: „Na aerodromu u Beogradu nas je dočekao maršal Tito u sivoplavoj uniformi sa zlatnim epoletama: neprikladnoj odeći za šefa komunističke države... Tito je bio poslednja preživela legendarna ličnost Drugog svetskog rata koja je još bila na vlasti - gerilski komandant o kojemu su pisane priče i napisi, prvi komunistički vođa koji se suprotstavio Staljinu, izumitelj nacionalističkog komunizma i sada jedan od prvaka nesvrstanosti... Njegovi maniri su bili nalik manirima nekog građanina srednje Evrope... Njegove se oči nisu smijale sa njegovim licem“. ${ }^{18}$

Uoči dolaska američke delegacije u Beograd, Kisindžer je smatrao da je postojalo nekoliko područja potencijalno plodne saradnje između SAD i SFRJ. Prema njegovim shvatanjima Beograd je bio koristan izvor obaveštenja o tendencijama u komunističkom svetu i svetu u razvoju. Kisindžer je u više navrata isticao da američki cilj nije podrazumevao pridobijanje Jugoslavije s obzirom na njenu nesvrstanu orijentaciju i politiku kojom su ispoljavani njeni vlastiti interesi. U više navrata je naglašavao značaj američkog odavanja priznanja nesvrstanima, posebno Jugoslaviji zbog vođenja ozbiljne politike. ${ }^{19}$

Posle Niksonove i Kisindžerove posete Jugoslaviji u Sjedinjenim Državama je stvorena povoljnija atmosfera prema Jugoslaviji (stavljeni su joj na raspolaganje značajni zajmovi, usledile su posete predsednika Svetske banke Roberta Maknamare Jugoslaviji i američkog sekretara poljoprivrede Hardina). ${ }^{20}$

Najveći domet u saradnji između dve države do tada je bio postignut $u$ političkim odnosima zahvaljujući poseti jugoslovenskog predsednika Tita Sjedinjenim Državama 1971. godine. Tom prilikom je usvojen dokument poznat kao Vašingtonska deklaracija koji je predstavljao trajnu osnovu odnosa nesvrstane Jugoslavije i SAD kao svetske sile. U deklaraciji su bili istaknuti sledeći principi: pregovaranje i saradnja, rešavanje sporova, nezavisnost, uzajamno poštovanje, puna ravnopravnost svih država bez obzira na razlike i sličnosti u njihovim društvenim, političkim i privrednim sistemima, pridržavanje duha i principa Povelje UN, usklađivanje interesa svih zemalja, velikih i malih, nedeljivost i međuzavisnost sveta, razoružanje, stabilnost i progres u svetu, potreba pomoći zemljama u razvoju itd. Posebno je bilo podvučeno da je ,politika nesvrstavanja Jugoslavije bila značajan faktor u međunarodnim odnosima“" i da su zemlje koje

${ }^{16}$ DA MSP, PA, 1970, SAD, f-170, 434736, Poseta američkog predsednika Niksona Jugoslaviji 20. septembra 1970.

${ }^{17}$ DA MSP, PA, 1970, SFRJ, f-7, 4, Zaključci sa užeg Kolegijuma DS od 9. oktobra 1970.

${ }^{18}$ H. Kisindžer, Memoari II, 142-146; M. Terzić, n. d., 26-30.

${ }^{19}$ H. Kisindžer, Memoari II, 142-146.

${ }^{20}$ DA MSP, PA, 1970, SFRJ, f-3, 187, Informacija o predlogu posete jugoslovenskog predsednika Tita Sjedinjenim Državama 18. decembra 1970. Opširnije o tome u: D. Bogetić, Jugoslovensko-američki odnosi 1961-1971, 321-335. 
su sprovodile takvu politiku zajedno sa ostalim svetom mogle pružiti aktivan doprinos razrešavanju svetskih problema. Takođe je bilo istaknuto da su odnose SAD i SFRJ karakterisali ravnopravnost i puno uzajamno uvažavanje koji su predstavljali i važan faktor mira i stabilnosti u Evropi. ${ }^{21}$

Pokazan je obostrani interes i spremnost za nastavljanje stalnih i širih međusobnih konsultacija, za dalje razvijanje svih oblika ekonomske saradnje, zajedničkih naučno-tehnoloških projekata i kulturno-umetničkih razmena. Međutim, kako je jačala politika nesvrstanosti kao realan faktor u svetu tako je rasla $i$ uloga SFRJ kao jedne od najaktivnijih nesvrstanih zemalja. To je rezultiralo jačanjem raznovrsnih pritisaka SAD na Jugoslaviju, što je imalo za posledicu zahlađenje u međusobnim političkim odnosima. SAD nije odgovarala aktivna uloga Jugoslavije među nesvrstanim zemljama. Sjedinjene Države su pokazivanjem interesovanja za nesvrstanu poziciju Jugoslavije u stvari želele da istaknu potrebu za distanciranjem Jugoslavije od SSSR-a. Najviše im je odgovaralo svođenje jugoslovenske politike u regionalne okvire pri čemu je Jugoslaviji trebalo obezbediti nezavisnost, teritorijalni integritet i ekonomski prosperitet, ali uz američku podršku i oslonac. Američka vlada je polazila od stava da se osnova bilateralne saradnje mogla proširiti kroz mogućnost američkog prisustva u Jugoslaviji. Sa stanovišta dugoročnih strateških interesa prema Jugoistočnoj Evropi, SAD su očekivale da bi svojim primerom Jugoslavija mogla podstaći i druge socijalističke zemlje na razvijanje novih formi bilateralne saradnje sa SAD. ${ }^{22}$

\section{Kisindžerova poseta Jugoslaviji 4. novembra 1974.}

Tokom 1974. godine, ponovo se zaoštravaju odnosi između SAD i Jugoslavije. Sjedinjene Države pokreću širok pritisak na Jugoslaviju sa ciljem da utiču na unutrašnji razvoj i spoljnu politiku zemlje i, koliko je moguće, ograniče jugoslovensku međunarodnu aktivnost i delovanje. Rezultat takve američke politike prema Jugoslaviji bio je zamrzavanje političkih odnosa između dve zemlje, dok je saradnja u drugim oblastima nastavljena. Sjedinjene Države nisu krile da im je smetala odlučna podrška Jugoslavije zemljama i narodima koji su se borili za slobodu, politički i ekonomski suverenitet, što je predstavljalo i jedan od motiva napada na Jugoslaviju koja se nalazila u prvim linijama borbe za realizaciju principa nesvrstane politike na međunarodnom planu. Američka strana je Jugoslaviju smatrala ,liderom“ u nesvrstanom svetu.

Za vreme Jomkipurskog rata 1973. godine, protivno američkim očekivanjima, jugoslovenska vlada je odobrila prelet sovjetskim avionima preko teritorije Jugoslavije i na taj način omogućila dostavljanje neophodne pomoći arapskim zemljama. Američka strana je takvo ponašanje jugoslovenskih vlasti tretirala kao direktno suprotstavljanje američkim interesima na Bliskom istoku. Zbog toga su u američkoj štampi, posebno onoj koju su kontrolisali jevrejski krugovi, objavljiva-

\footnotetext{
${ }^{21}$ AJ, KPR, I-2/SAD, Jugoslovensko-američka zajednička izjava.

${ }^{22}$ AJ, KPR, I-3-a/ SAD, Kisindžerova poseta Jugoslaviji, 04. novembra 1974.
} 
ni napisi u kojima se oštro napadalo držanje Jugoslavije i dovodila u pitanje njena nesvrstanost. Američki establišment je očekivao da njihovi partneri vode računa i poštuju njihove vitalne interese s obzirom na činjenicu da je time američki stav prema Jugoslaviji bio u najvećoj meri uslovljen. U tom smislu su Amerikanci prema nesvrstanim zemljama primenjivali selektivnu politiku i nastojali da razbiju jedinstvo nesvrstanih. Ugled i uticaj posebno aktivnost Jugoslavije u pitanjima gde je već postojalo jedinstvo nesvrstanih zemalja, svakako su smetali zamislima i globalnim koncepcijama američke spoljne politike. ${ }^{23}$

Američki establišment je pokazivao posebno veliko interesovanje za razvoj situacije unutar Jugoslavije u slučaju odlaska jugoslovenskog predsednika sa političke scene. Prema američkim procenama, jugoslovenska komunistička partija je jačala uticaj u zemlji dok je armija predstavljala čvršći amalgam jedinstva zemlje. ${ }^{24}$ Pojedini američki generali (Vilson) tvrdili su da američki cilj nije podrazumevao privlačenje Jugoslavije u NATO već zalaganje da Jugoslavija ostane nesvrstana, ali na takav način da ne bude u ulozi predvodnika i zastupnika drugih zemalja i pokreta u borbi protiv SAD (kao što je to bio slučaj kada su jugoslovenski predstavnici u OUN išli ispred zahteva Egipćana). ${ }^{25}$

Očigledno je bilo da je do druge posete američkog državnog sekretara Kisindžera Jugoslaviji došlo u vreme veoma složene i teške međunarodne situacije. Otvorena su mnoga krupna međunarodna ekonomska i politička pitanja od čijeg rešavanja su velikim delom zavisili pravci kretanja međunarodnih odnosa. Odlaskom Niksona sa funkcije američkog predsednika i izborom novog predsednika Džeralda Forda nije došlo do bitnih promena u osnovnim strateškim ciljevima američke spoljne politike, ali je došlo do izvesnih promena u redosledu njenih prioriteta. Prevlast državnog sekretara Kisindžera u oblasti spoljne politike nije bila dovedena u pitanje. Kisindžer je uspeo da ostane, odnosno da zadrži i funkciju savetnika za nacionalnu bezbednost. ${ }^{26}$

Detant i odnosi sa SSSR-om i NR Kinom, zajedno sa naporom da učvrsti svoje pozicije nespornog hegemona unutar zapadnog saveza, ostali su među najvažnijim pravcima američke spoljne politike. Detant je ostao za SAD jedno od sredstava kojim se nastojao obezbediti položaj vodeće sile u svetu. SAD su i dalje pokazivale posebno veliki interes za kretanje u pojasu Mediterana (Pirinejsko poluostrvo, Apeninsko poluostrvo, Kipar, Grčka i Turska), Bliski istok, itd. Međunarodna ekonomska pitanja su sve više dolazila u prvi plan američke spoljne politike, budući da su međunarodni monetarni i ekonomski odnosi bili prostor gde su SAD obezbeđivale svoju dominantnu neokolonijalističku poziciju u posleratnom periodu i vodeću ulogu među zapadnim saveznicima. SAD su uviđale da je dalje zaoštravanje međunarodnih ekonomskih odnosa moglo ozbiljno ugroziti stabil-

${ }^{23}$ DA MSP, PA, 1974, SAD, f-130, 451443, Poljoprivreda i prehrambena industrija.

${ }^{24}$ Yugoslavia After Tito, „From 'National Communism' to National Collapse, US Intelligence Community. Estimate Products on Yugoslavia 1948-1990".

${ }_{25}$ DA MSP, PA, 1974, SAD, f-1, 36, Razgovor sa generalom Vilsonom, zamenikom direktora vojno-obaveštajne službe armije SAD.

${ }^{26}$ R. Šulcinger, $n$. d., 299. 
nost njenih najvažnijih partnera u Zapadnoj Evropi i u celini globalne pozicije Sjedinjenih Država u svetu. Zbog toga su nastojale da izvrše pritisak na zemlje u razvoju, proizvođače važnih primarnih sirovina i nafte u cilju zaustavljanja rasta cena i zadržavanja privilegovanih pozicija visoko razvijenih industrijskih zemalja u svetskoj razmeni i raspodeli. Ovakva politika je dovela Sjedinjene Države u konfrontaciju i sukob sa nesvrstanim zemljama, koje su na Četvrtoj konferenciji nesvrstanih zemalja u Alžiru (1973) iznele program temeljne izmene dotadašnjeg sistema međunarodnih ekonomskih i političkih odnosa i ponašanja u svetu. Sukob između SAD i nesvrstanih se zahuktavao i predstavljao je razlog izvesnog zaoštravanja američke politike prema Jugoslaviji, ali istovremeno i povećanog interesa s obzirom na njenu poziciju među nesvrstanim zemljama. ${ }^{27}$

Između dve zemlje je, uprkos mnogobrojnim „,varnicama“, tokom 1974. godine nastavljena ekonomska saradnja po ustaljenoj praksi i intenzitetu. Između ostalog potpisan je Sporazuma o nuklearnoj elektrani Krško, ${ }^{28}$ osnovane su američka i jugoslovenska komora za unapređenje privredne, tehničke i naučne saradnje, povećana je robna razmena, izvoz je povećan za 49\%, a uvoz za 95\%. Zaključeno je više novih kreditnih aranžmana, potpisani su sporazumi o zajedničkim ulaganjima u vrednosti od oko 9 miliona dolara, nastavljena je uspešna naučnotehnološka saradnja i postignuti su određeni rezultati u kulturno-prosvetnoj saradnji. Najverovatnije su ovi potezi značili da je američka strana uvidela da svi pokušaji primene politike pritiska na Jugoslaviju nisu bili produktivni i da nisu davali očekivane rezultate, već da bi trebalo primeniti metode „meke moći“.

Strateški američki interesi na području Mediterana, Bliskog istoka i Balkana određivali su potrebu nastavljanja svestrane saradnje sa Jugoslavijom. Američka vlada je tokom krize u regionu Mediterana videla u nezavisnoj i stabilnoj Jugoslaviji stabilizirajući faktor na tom području. Osnovnu snagu Jugoslavije prema Sjedinjenim Državama predstavljala je jugoslovenska politika nesvrstavanja i njena aktivna uloga u zajedničkom delovanju sa drugim nesvrstanim zemljama na širokom međunarodnom planu. Sjedinjenim Državama je međutim smetala jugoslovenska aktivnost na svim kriznim područjima na Bliskom istoku, Kipru i drugde. ${ }^{29}$

Upravo u takvim okolnostima četiri godine posle prve posete Jugoslaviji usledila je nova poseta američkog državnog sekretara Kisindžera koja je, između ostalog, imala i cilj da ukaže Sovjetskom Savezu na postojanje značajnih američkih interesa u Jugoslaviji i da isključi Moskvu iz posredničke uloge u komunikaciji. Očekivalo se da se tokom posete Kisindžer koncentriše na bitna pitanja kojima je trebalo odrediti dugoročnost odnosa dve zemlje, i to pre svega na jugoslovenska gledišta o nesvrstanoj politici i njene praktične akcije, kao i na razvoj međuarmijske saradnje dve zemlje. Sa američke strane su bili nagovešteni razgovori o međunarodnim

27 Dragan Bogetić, „Jugoslovensko-američke nesuglasice oko koncepta novog međunarodnog ekonomskog poretka“, Istorija 20. veka, br. 1, (2014), 165-180; AJ, KPR, I-4-a/15. Četvrta konferencija šefova država ili vlada nesvrstanih zemalja, Alžir, 5-10. septembar 1973.

${ }^{28}$ O izgradnji elektrane Krško: Dragomir Bondžić, Između ambicija i iluzija. Nuklearna politika Jugoslavije 1945-1990 (Beograd: Institut za savremenu istoriju, 2016), 355-362, 396-399.

${ }^{29}$ AJ, KPR, I-3-a/ SAD, Kisindžerova poseta Jugoslaviji, 04. novembra 1974. 
temama koje su obuhvatale krizna područja (Kipar i Bliski istok, odnose IstokZapad, Mediteran). Osnovni cilj posete se svodio na razvoj odnosa sa Sjedinjenim Državama i održanje stabilne saradnje u svim oblastima na principima Vašingtonske deklaracije (1971). Takav cilj je predstavljao iskorak u međusobnim odnosima budući da je usledio posle perioda pojačanih američkih pritisaka na Jugoslaviju.

Jugoslovenski predsednik je u očima Amerikanaca predstavljan kao nacionalista koji je brinuo za nezavisnost i bezbednost sopstvene zemlje. Američka strana ga je doživljavala kao ličnost čije su reči i dela često bila u raskoraku. Prema američkim opaskama njegove su ,reči naginjale Istoku a akcije Zapadu“. Kao ideolog je bio bliži Moskvi, dok je u svetskoj politici izgradio vezu sa zemljama Trećeg sveta. Posebna opaska sa američke strane se odnosila na način života jugoslovenskih naroda koji se u velikoj meri razlikovao od ,života njegovih sovjetskih kolega a bio mnogo bliži životu nekih zapadnih naroda“ “ 30

Američki državni sekretar je u Jugoslaviji tretiran kao jedan od tada najizuzetnijih državnika na svetu, zadužen za rešavanje hladnoratovskih kriza. Bez obzira što je u nekim krugovima bio predstavljan kao kontradiktorna ličnost zbog svog odnosa prema zemljama Trećeg sveta, jugoslovenski establišment je pokazivao veliki respekt prema njegovim programima i aktivnostima. Značaj Kisindžerovog dolaska u Beograd i njegovih susreta sa najvišim jugoslovenskim rukovodiocima ležao je u činjenici da su prvi put bili obavljeni razgovori na visokom nivou sa novom američkom administracijom posle Desetog kongresa SKJ i usvajanja novog jugoslovenskog Ustava. ${ }^{31}$

Dugogodišnje iskustvo je ukazivalo na postojanje ozbiljnih razlika u jugoslovensko-američkim gledištima na mnoga međunarodna pitanja. Jugoslavija je bila pobornik stava po kome sve ono što je predstavljalo suvereno pravo jedne zemlje nije smelo zadirati u suvereno pravo druge. Svima koji ta prava nisu poštovali Jugoslavija je bila spremna da se suprotstavi (pa čak i američkoj spoljnoj politici). Jugoslovenske vlasti su smatrale da takva politika Jugoslavije nije značila antiamerikanizam već suštinsko neslaganje i otpor svim pokušajima narušavanja osnovnih principa međunarodnih odnosa. Na taj način Jugoslavija je branila i nastojala da očuva sopstvenu nezavisnost, suverenitet i integritet. Jugoslovenski establišment je pružao otpor svakom mešanju sa strane i ometanju nezavisnog razvoja svake zemlje, i time se suprotstavljao proklamovanoj američkoj politici intervencionizma. ${ }^{32}$

Prema mišljenju američke administracije budućnost Jugoslavije se zasnivala na pretpostavkama da je samo održiva, integralna i nezavisna Jugoslavija koja nije bila deo Varšavskog pakta niti članica NATO mogla biti od životnog značaja za održavanje sistema bezbednosti u Evropi. Ozbiljniji unutrašnji sukobi u Jugoslaviji kao i radikalne promene njene spoljne politike mogli su negativno uticati na detant $\mathrm{u}$ Evropi. Američki establišment je smatrao da je Savez komunista Jugoslavije, za raz-

\footnotetext{
${ }^{30}$ D. Bogetić, Jugoslovensko-američki odnosi u vreme bipolarnog detanta 1972-1975, 15-16.

${ }^{31}$ Deseti kongres SKJ je održan od 27. maja do 30. maja 1974. u Beogradu. Na Kongresu je podvučen značaj demokratskog centralizma, prihvaćena je koncepcija samoupravljanja zasnovana na udruženom radu, a Tito je izabran za predsednika SKJ bez ograničenja mandata.

${ }^{32}$ AJ, KPR, I-3-a/ SAD. Kisindžerova poseta Jugoslaviji, 04. 11. 1974.
} 
liku od svih drugih komunističkih zemalja, predstavljao političku instituciju za očuvanje države. Prema navodima američkog političkog vrha Jugoslavija je posle 1971. godine povela kurs ,stezanja“, ali ne i vraćanja na sovjetski ili (rumunski) unutrašnji politički sistem. Partija je nastojala da ograniči šovinizam tako što je jačala afirmaciju različitih nacionalnih grupa u okviru šire jugoslovenske zajednice. Na taj način partija je pokušala da ponovo stvori svejugoslovenski centar koji je imao zadatak da utiče na partijske organizacije od kojih se sastojao, ali ne i da im zapoveda. ${ }^{33}$

Dok se u Jugoslaviji sa nestrpljenjem iščekivala Kisindžerova poseta, u Americi je istovremeno tekla oštra kampanja protiv njega i njegove neuspele politike u rešavanju Kiparske krize. Na oštre kritike upućene Kisindžeru, naročito posle vojnog povlačenja Grčke iz NATO, nadovezala se i afera oko njegove uloge i učešća američke obaveštajne službe CIA u prevratu u Čileu. U Vašingtonu su krah Kisindžerove politike u rešavanju Kiparske krize doživeli kao nanošenje štete američkim interesima u celom tom regionu i šire u NATO. Zato je od predsednika Džeralda Forda tražena Kisindžerova ostavka. Američki predsednik je, međutim, ocenio da bi odstranjivanje Kisindžera sa položaja i funkcije moglo imati teške reperkusije u smislu gubitka poverenja sveta u američku politiku. Uprkos pritiscima, predsednik Ford je pružio podršku Kisindžeru i odlučio da ga zadrži na obe funkcije. ${ }^{34}$ Novoizabrani američki predsednik Ford je uputio poruku jugoslovenskom predsedniku Titu u kojoj je izrazio želju za nastavkom saradnje i daljim unapređenjem bilateralnih odnosa na bazi principa iz Zajedničke izjave 1971. godine. Tom prilikom američki predsednik je istakao značaj nezavisne i nesvrstane Jugoslavije kao i njene pozicije. U sklopu takve američke politike državni sekretar Kisindžer je uputio poruku svom kolegi, jugoslovenskom državnom sekretaru Milošu Miniću, kojom je nastojao da potvrdi kontinuitet američke politike i nameru da poseti Jugoslaviju. ${ }^{35}$

Međutim, nastup jugoslovenskog predsednika u Jesenicama vezan za događaje na Kipru doveo je do bure protesta i nezadovoljstva u Vašingtonu. Tom prilikom je jugoslovenski predsednik izneo ozbiljne optužbe na račun CIA kao mogućeg organizatora kiparskog puča. Ovakve optužbe su mogle postati i povod za moguće otkazivanje Kisindžerove posete Jugoslaviji. Zbog svih dešavanja ni sam američki državni sekretar nije bio siguran da li će Jugoslavija ostati uvrštena u njegov program putovanja. Glavnim krivcem za mogući negativan razvoj odnosa između dve zemlje Kisindžer je smatrao jugoslovenskog predsednika Tita. Tom prilikom Kisindžer je otvoreno zapretio jugoslovenskoj vladi rekavši: „Nije bezbedno da se napadaju SAD, odnosno niko nas neće napadati i očekivati pomoć. “36

Poseta Beogradu je predstavljala samo jednu od stanica u okviru Kisindžerove turneje po zemljama koje su se nalazile u širokoj zoni južnih granica SSSR

${ }^{33}$ DA MSP, PA, 1974, SAD, f-124, 455534, Mišljenje američkog establišmenta o budućnosti Jugoslavije, 31. oktobar 1974.

${ }^{34}$ DA MSP, PA, 1974, SAD, f-124, 445570, Informacija predsednika Forda u vezi delatnosti i zadataka CIA, 23. septembar 1974.

${ }^{35}$ DA MSP, PA, 1974, SAD, f-124, 443242, Informacija o uticaju smene predsednika SAD na američku politiku, 9. septembar 1974.

${ }^{36}$ Dragan Bogetić, „Kiparska kriza 1974. i pogoršanje jugoslovensko-američkih odnosa“, Tokovi istorije, br. 3, (2104), 123-124. 
(Italija, Rumunija, Iran, Avganistan, Indija, Bangladeš, Pakistan). Na poziv potpredsednika Saveznog izvršnog veća (SIV) i saveznog sekretara za inostrane poslove Miloša Minića američki državni sekretar Kisindžer je posetio Jugoslaviju 4. novembra 1974. godine. Tom prilikom sa Kisindžerom su se sastali potpredsednik SIV-a Džemal Bijedić i savezni sekretar za inostrane poslove Miloš Minić, kao i predsednik Tito. Razgovori prilikom ovih susreta, vođeni u atmosferi prijateljstva i otvorenosti, obuhvatali su najaktuelnija međunarodna pitanja i bilateralne odnose. Najvažnije mesto u razgovorima zauzimala je politika nesvrstavanja, posebno delovanje i aktivnost Jugoslavije na tom polju kao i stavovi američke vlade prema nesvrstanoj politici i aktivnostima nesvrstanih zemalja. Posebna pažnja je bila posvećena kriznim područjima u svetu kao što su bili Bliski istok i Kipar. Dve strane su izložile svoja gledišta o putevima rešavanja aktuelnih svetskih problema i potvrdile važnost održavanja redovnih kontakata i konsultacija na svim nivoima. Posebna pažnja je bila posvećena problemima u oblasti međunarodnih ekonomskih kretanja i odnosa. Naglašavajući da su dve zemlje i narodi u osnovi bili međuzavisni, pokazana je i saglasnost u činjenici da su stvarni mir i stabilnost mogli biti postignuti jedino uz znatan napredak u rešavanju gorućih problema pred kojima se nalazilo čovečanstvo u oblasti međunarodnih ekonomskih odnosa, svetske privrede i razvoja. Trajna rešenja takvih problema su mogla biti ostvarena samo poštovanjem nezavisnosti, suvereniteta i ravnopravnosti država bez obzira na njihove slične ili različite društvene, ekonomske ili političke sisteme. Predstavnici dve strane su se tokom razgovora zalagali za ravnopravnu saradnju svih članica međunarodne zajednice na bazi poštovanja principa Povelje Ujedinjenih nacija pri rešavanju otvorenih međunarodnih problema. Pri tom je istaknut značaj jugoslovenske nesvrstane politike kojom je bilo postignuto veće i bolje razumevanje među narodima i traženje mirnih rešenja za međunarodne probleme i sukobe. Dve strane su takođe ocenile da je bilateralna saradnja bila povoljna i pokazale su spremnost za njeno unapređenje i proširenje, naročito na polju ekonomske, finansijske, tehnološke saradnje kao i zajedničkih ulaganja. Posebno su naglasile značaj sporazuma na osnovu kojeg su američka i jugoslovenska preduzeća sarađivala u izgradnji prve jugoslovenske nuklearne elektrane. Obe zemlje su pokazale spremnost da aktivno rade na daljem proširivanju međusobne kulturne saradnje. ${ }^{37}$

Tokom razgovora sa predsednikom SIV-a Džemalom Bijedićem obe strane su došle do zaključka da su se bilateralni odnosi i sveukupna saradnja između Jugoslavije i SAD razvijali dobro i u duhu prijateljstva. Odnosi prijateljstva i saradnje sa Sjedinjenim Državama su predstavljali bitan element jugoslovenske spoljne politike. Predsednik SIV-a je smatrao da se jugoslovenska privreda nalazila na nivou koji je zahtevao veću ekspanziju na bazi najmodernije tehnologije i opreme i u tom kontekstu Sjedinjene Države je doživljavao kao važnog partnera. Bijedić je ukazao na interes jugoslovenskih privrednih organizacija za unapređenje saradnje na bazi korišćenja znanja, moderne tehnologije i američkog finansijskog

37 DA MSP, PA, 1974, SAD, f-130, 454873, Izveštaj o zvaničnoj poseti američkog državnog sekretara Kisindžera Jugoslaviji 4. novembra 1974. Videti još o tome u: D. Bogetić, Jugoslovensko-američki odnosi u vreme bipolarnog detanta 1972-1975, 161-165. 
učešća. Ovakvi jugoslovenski zahtevi su presudno uticali na donošenje odluke o izgradnji prve nuklearne elektrane u Jugoslaviji od strane američke firme Vestinghaus (Westinghouse). Predsednik SIV-a se zalagao i za nastavak uspešne saradnje sa američkom Exim bankom. Naglasio je potrebu Jugoslavije za korišćenjem opšte šeme preferencijala SAD. Zahvaljujući ovakvoj saradnji sa SAD, Jugoslavija se našla u prilici da donese novi zakon o zajedničkim ulaganjima stranog kapitala.

Za razliku od drugih segmenata saradnje, u oblasti vojno-ekonomske saradnje stvari se nisu razvijale zadovoljavajućim putem. Tokom razgovora sa jugoslovenskim predstavnicima američki državni sekretar Kisindžer je primetio da su saradnju na tom polju kočile i zamrzle Sjedinjene Države. Predsednik SIV-a je navodio mnogobrojne loše aspekte vojne saradnje koje je potkrepljivao negativnim primerima. Jedan od njih se odnosio na posedovanje američkih topova i njihovu neupotrebljivost zbog nedostatka municije koja nije dolazila iz SAD. Sve vojne nabavke iz SAD su se svodile na marginalne nabavke rezervnih delova $\mathrm{i}$ municije za oružje američke proizvodnje, nabavljeno ranijih godina kojeg je još bilo u naoružanju JNA a koje više nije bilo moguće nabaviti, istakao je Bijedić. Stoga se od američkog državnog sekretara Kisindžera očekivalo da predloži konkretne kontakte na tom planu koji bi imali za cilj unapređenje vojne saradnje. ${ }^{38}$

Jugoslovenski i američki državni sekretar su takođe vodili razgovore o aktivnostima svojih zemalja na međunarodnom planu. Kisindžer je podržavao sve jugoslovenske aktivnosti koje su bile u funkciji očuvanja nezavisnosti Jugoslavije. Savezni sekretar Minić je izneo šira jugoslovenska gledišta o aktivnostima nesvrstanih zemalja i njihovoj ulozi u globalnim svetskim odnosima. Podvukao je da se orijentacija nesvrstanih zemalja i njihovih ciljeva i zahteva ostvarivala kroz saradnju sa svim državama, uključujući i velike sile SAD, SSSR i Kinu, uz izbegavanje konfrontacija i stvaranje novog bloka, glasačke mašine OUN. Kisindžer je pokazao razumevanje za principe politike nesvrstavanja, ali je naglasio da su se u praksi nesvrstane zemlje suprotstavljale svim američkim akcijama. Ukazao je na zabrinutost američke strane zbog mogućeg prerastanja pokreta nesvrstanih kroz zajedničke aktivnosti u novi blok. Nastojao je da pridobije naklonost i razumevanje jugoslovenske vlade za američku politiku rešavanja bliskoistočne krize „,korak po korak“. Posebno je isticao američki interes za njenim trajnim rešenjem.

Samit u Rabatu, ${ }^{39}$ međutim, oslabio je američku pregovaračku poziciju oko prevazilaženja krize na Bliskom istoku. Američki državni sekretar je, naime, imao zadatak da postigne dogovor sa predstavnicima Palestinske oslobodilačke organizacije kao jedinim reprezentom palestinskog naroda. Prema mišljenju američkog državnog sekretara, Samit u Rabatu je samo doveo do komplikacija u sprovođenju američke strategije postepenog rešavanja problema Bliskog

${ }^{38}$ DA MSP, PA, 1974, SFRJ, f-7, 589, Razgovor predsednika SIV-a Dž. Bijedića sa američkim državnim sekretarom H. Kisindžerom 04. novembra 1974; FRUS, 1969-1976, Volume E-15, Part 1, Documents on Eastern Europe, 1973-1976, Yugoslavia, doc 71. Memorandum of Conversation, Belgrade, November 4, 1974.

${ }^{39}$ Samit u Rabatu (Maroko) održan je oktobra 1974. i okupio je lidere dvadeset arapskih zemalja. Usvojena je Rezolucije kojom je Palestinska oslobodilačka organizacija prvi put priznata od strane arapskih zemalja kao jedini legitimni predstavnik palestinskog naroda. 
istoka. Kisindžer je smatrao da je jedino vlada SAD imala mogućnost da posreduje između zaraćenih strana na Bliskom istoku. Jugoslovenski establišment predvođen predsednikom Titom nije podržavao takav američki stav, a još manje ,američko relativizovanje izraelske krivice za eskalaciju sukoba na Bliskom istoku“. Sve upućuje na konstataciju da susret dvojice državnika nije doveo do saglasnih rešenja vezanih za bliskoistočnu krizu. ${ }^{40}$

$\mathrm{Za}$ razliku od bliskoistočne krize, tokom razgovora o situaciji na Kipru američki državni sekretar je veoma detaljno izložio američke stavove o mogućim načinima rešavanja te krize. Insistirao je na pružanju američke podrške Kipru u cilju očuvanja njegovog suvereniteta i teritorijalnog integriteta. Svi ti Kisindžerovi napori trebalo je da pokažu da SAD nisu imale nikakvog interesa za otvaranje novog žarišta u tom delu sveta kao ni za izvođenje puča na Kipru. Rešenje kiparskog problema američka strana je videla na federativnoj osnovi koja bi predstavljala rezultat sporazuma dve zajednice. ${ }^{41}$ Jugoslovenskom predsedniku se Kisindžerov stav o rešenju kiparskog problema na federalnom sistemu sa nekim geografskim principima nije činio nimalo realnim. Jugoslovenska strana je morala biti veoma oprezna tokom angažmana oko rešavanja kiparskog problema budući da je zbog svog eksponiranja u toj sferi plaćala visoku cenu i pri tom stavljala $u$ drugi plan svoj vitalan interes za poboljšanje odnosa sa SAD. ${ }^{42}$

$\mathrm{Na}$ kraju razgovora dve strane su se dotakle još jednog problema koji je opterećivao međusobne odnose. Reč je o tršćanskoj krizi koja je eskalirala zbog oštrih jugoslovensko-italijanskih sukoba oko nekadašnje Zone B. Američka Šesta flota, naime, bila je u sadejstvu sa italijanskim oružanim snagama uključena u manevre u severnom Jadranu, blizu Trsta. Takvi američki potezi su u Jugoslaviji tumačeni kao američka podrška italijanskim teritorijalnim pretenzijama prema Jugoslaviji. ${ }^{43}$ Američka strana je pokazala interes za rešavanje pitanja Trsta na bazi pregovora koji bi predstavljali veliki doprinos atmosferi popuštanja zategnutosti u Evropi. Dve strane su naposletku saglasno zaključile: tršćansko pitanje treba da bude rešeno bilateralno, odnosno između dve zemlje. Obostrano se došlo do konstatacije da bi takav rasplet predstavljao istovremeno praktičan i konkretan doprinos u okviru KEBS-a. ${ }^{44}$

Politika američkog državnog sekretara prema Jugoslaviji ukazala je na potrebu konstantnog političkog dijaloga na najkompetentnijem nivou između dve države s obzirom na postojanje obostranog interesa za nastavljanje i jačanje međusobnih odnosa i saradnje uz razjašnjavanje i ublažavanje elemenata koji su predstavljali smetnju takvom razvoju. Posete na najvišem nivou od dolaska Niksona u Jugoslaviju, Tita u SAD i Kisindžera u Beograd pokazale su da je glavni cilj bila manifestacija dobrih odnosa sa Jugoslavijom u toku globalnih američkih aktivnosti kao i pridobi-

\footnotetext{
${ }^{40}$ D. Bogetić, Jugoslovensko-američki odnosi u vreme bipolarnog detanta 1972-1975, 161-165.

${ }^{41}$ DA MSP, PA, 1974, SFRJ, f-130, 45349, Depeša iz Kabineta saveznog sekretara, 7. novembra 1974.

42 D. Bogetić, ,Kiparska kriza i pogoršanje jugoslovensko-američkih odnosa“, 127-128.

43 AJ, KPR, I-3-a/107-210, Jugoslovensko-italijanski odnosi.

44 DA MSP, PA, 1974, SAD, str. pov. 510, Stenografske beleške razgovora između saveznog sekretara za inostrane poslove M. Minića i američkog državnog sekretara H. Kisindžera, 4. novembra 1974.
} 
janje podrške i razumevanja jugoslovenske strane za neposredno američko angažovanje na Bliskom istoku i Kipru. Kisindžerovom posetom Sjedinjene Države su nastojale pokazati Sovjetima da u zemljama kao što je Jugoslavija imaju značajne interese i da se žele suprotstaviti sovjetskim pokušajima korišćenja detanta za prodor u ova područja. Kisindžerova poseta je označavala završetak faze ,zamrzavanja“ političkih odnosa koji su postojali zbog američkih pritisaka na Jugoslaviju. Čak je i američka procena bila da zamrznuti politički odnosi i pritisci na Jugoslaviju nisu dali očekivane rezultate, već su se pokazali kontraproduktivnim sa stanovišta njihovih širih i dugoročnijih interesa prema njoj. Kisindžer je nastojao da ostavi utisak razumevanja i uvažavanja jugoslovenske politike nesvrstavanja. Smatrao je, međutim, da su praktična primena politike nesvrstavanja i usaglašeno istupanje, posebno zajedničke konkretne akcije nesvrstanih zemalja u OUN, odudarali od strateških američkih interesa. Traženje dodirnih tačaka sa Jugoslavijom na planu međunarodnih odnosa pokazalo je američku spremnost da neke globalne probleme (energija, sirovine, hrana) rešava na širokoj osnovi uz učešće zemalja u razvoju, koje nisu prihvatale kao partnere već kao faktor koji se silom prilika nije mogao ignorisati. Preko saradnje i dobrih odnosa sa Jugoslavijom, SAD su želele uticati ne samo na jugoslovensku politiku već i na pokret nesvrstanosti u celini, u cilju smanjivanja otpora američkim strateškim ciljevima i aktivnostima na međunarodnom planu. Razgovori sa Kisindžerom predstavljali su potvrdu i aktuelizaciju temelja međusobnih odnosa formulisanih u Zajedničkoj izjavi 1971. godine. Poseta je bila od značaja ne samo za jugoslovensku saradnju sa SAD, već i za međunarodnu poziciju Jugoslavije.

Kisindžer se zalagao i za konkretne korake na polju vojne saradnje dve zemlje. Osvrnuvši se na različite geografske pozicije, istoriju i ideologiju dve zemlje, istakao je postojanje svesti kod američke strane o posebnosti jugoslovenskih potreba. Krajnji cilj SAD u odnosu na Jugoslaviju bazirao se na očuvanju njene nezavisnosti, stabilnosti i jedinstva u odnosu na SSSR. Razvijanje dobrih odnosa između dve zemlje predstavljalo je jednu od glavnih komponenti spoljne politike Jugoslavije kroz čitav posleratni period.

Osnovnu snagu Jugoslavije prema SAD predstavljala je jugoslovenska dosledna politika nesvrstavanja i njena aktivna uloga u zajedničkom delovanju sa drugim nesvrstanim zemljama na širokom međunarodnom planu. Poseta američkog državnog sekretara je sa jugoslovenske strane bila ocenjena kao korisna i prema viđenjima jugoslovenskog političkog vrha nije unela u međusobne odnose elemente suštinskih promena.

\section{REFERENCE}

- Bogetić, Dragan. Jugoslovensko-američki odnosi 1961-1971. Beograd: ISI, 2012.

- Bogetić, Dragan. „Kiparska kriza 1974. i pogoršanje američko-jugoslovenskih odnosa“. Tokovi istorije, br. 3, (2014), 111-129.

- Bogetić, Dragan. „Jugoslovensko-američke nesuglasice oko koncepta novog međunarodnog ekonomskog poretka“. Istorija 20. veka, br. 1, (2014), 165-180. https://doi.org/10.29362/ist20veka.2014.1.bog.165-180 
- Bogetić, Dragan. Jugoslovensko-američki odnosi u vreme bipolarnog detanta 1972-1975. Beograd: ISI, 2015.

- Bondžić, Dragomir. Između ambicija i iluzija. Nuklearna politika Jugoslavije 1945-1990. Beograd: Institut za savremenu istoriju, 2016.

- Golan, Matti. The secret conversation of Henry Kissinger. Step by step Diplomacy in the Middle East. New York: Quadrangle/The New York times Book Co, 1976.

- Kalb Marvin, and Bernard Kalb. Kissinger. New York: Dell Publishing, 1975.

- Kissinger, Henry. Memoari I-II. Zagreb: Vjesnikova Press agencija, 1981.

- Radović, Sanja. „Jugoslovenski pogled na kinesku politiku otvaranja u periodu 1970-1972. godine“. Tokovi istorije, br. 2, (2013), 234-235.

- Terzić, Milan. Tito i Nobelova nagrada za mir. Podgorica: Pobjeda, 2006.

- Šulcinger, Robert D. Američka diplomatija od 1900. godine. Beograd: Udruženje za studije SAD u Srbiji, 2011.

TATJANA MILOŠEVIĆ, PhD, Research Assistent

Strategic Research Institute

Belgrade, Republic of Serbia

tatjana74.milosevic@gmail.com

\section{YUGOSLAVIA AND UNITED STATES OF AMERICA IN THE ERA OF DETANTE: MEETINGS BETWEEN JOSIP BROZ TITO AND HENRY KISSINGER 1970-1974}

\section{Summary}

Cooperation between Yugoslavia and USA was continued even after the election of new American president and administration during 1969. In the era of detante Americans created a low-profile policy. Bilateral cooperation between Yugoslavia and the USA has significantly increased as compared to the previous period. US presence in Yugoslavia increased in the area of economy, culture, military development and on the political level. Kissinger's visit to Yugoslavia had a large impact especially on the Yugoslav-US political relations and had confirmed the values and importance of the principles of the Washington Declaration. During 1974 US foreign policy has accepted and approved Yugoslav position in the Non-alignement movement. The development of good relations between the two countries was one of the main components of Yugoslav foreign policy through that period. The final American aim was to preserve Yugoslav indepedence, stability and unity in relation to the USSR. Both sides had reached the consensus that the peace and stability in the world was impossible to achieve without progress in solving economic issues. Kissinger's visit marked the end of the phase of „freezing" political relations due to US pressure on Yugoslavia.

KEYWORDS: Yugoslavia, USA, Josip Broz Tito, Henry Kissinger, Richard Nixon, Gerald Ford, Non-aligned countries, Middle East and Cyprus Crisis 